P. Slinger MD FRCPC

\title{
New trends in anaesthesia for thoracic surgery including thoracoscopy
}

This seminar will deal with the recent advances in the anaesthetic management of patients having thoracic surgery. Specific areas in which there have been important innovations are: preoperative assessment, intraoperative monitoring, lung isolation techniques, management of one-lung anaesthesia, thoracoscopy and postoperative analgesia.

\section{Preoperative assessment}

The morbidity and mortality rates for pulmonary resections are among the highest for any common elective surgical procedure. The 30-day operative mortality rate is approximately $4 \%{ }^{1}$ and severe cardiorespiratory complications occur in $30-50 \%{ }^{2}$ of cases. Patients referred for surgery will usually have already met minimal surgical criteria for operability. ${ }^{3}$ However, among the patients with potentially resectable lesions those at increased risk for perioperative morbidity and mortality should be identified:

1 Preoperative pulmonary function: The predicted postoperative forced expiratory volume in one second $\left(\mathrm{FEV}_{\mathrm{l}}\right)$ is the single most useful indicator of early morbidity. ${ }^{4}$ A postoperative $\mathrm{FEV}_{1}<40 \%$ of the predicted normal is associated with increased morbidity and mortality. The majority of patients with a predicted $\mathrm{FEV}_{1}<30 \%$ will require ventilatory support at some time in the postoperative period. 5

A large proportion of the patients for thoracic surgery have chronic obstructive pulmonary disease (COPD). Among patients with moderate or severe COPD (i.e., $\mathrm{FEV}_{1}<65 \%$ predicted) it is not possible to predict on the basis of history, physical or spirometry, which patients are " $\mathrm{CO}_{2}$-retainers." ${ }^{6}$ These patients are all at risk of requiring mechanical ventilation post-thoracotomy. Thus, to aid in postoperative weaning, any thoracic surgical patient with COPD needs an arterial blood gas analysis preoperatively.

The diffusing capacity for carbon monoxide (DLCO) is an independent predictor for post-thoracotomy respiratory complications. ${ }^{7}$ A preoperative DLCO $>80 \%$ predicted is associated with $\mathrm{a}<10 \%$ incidence of postoperative respiratory complications while a DLCO $<60 \%$ has a $>30 \%$ risk. $^{8}$ For potential pneumonectomies it may be possible to downgrade the estimated risk on the basis of a preoperative ventilation/perfusion $(\dot{V} / \dot{Q})$ scan. $^{9}$

Exercise tolerance may become the most specific predictor of post-thoracotomy cardio-respiratory complications. A maximum oxygen consumption $\left(\mathrm{VO}_{2} \max \right)>20$ $\mathrm{ml} \cdot \mathrm{kg}^{-1} \cdot \mathrm{min}^{-1}$ is associated with a low incidence of complications while a $\mathrm{VO}_{2} \max <15 \mathrm{ml} \cdot \mathrm{kg}^{-1} \cdot \mathrm{min}^{-1}$ has a very high risk. ${ }^{10}$ Stair climbing is a similar but less reproducible test. ${ }^{11}$

2 Age: Recent studies suggest that age is no longer a major independent risk factor ${ }^{12}$ for mortality although morbidity rates are higher in the elderly.

3 Surgical incision: Many resections can be done with a median sternotomy. This is associated with lower morbidity and better postoperative pulmonary function. ${ }^{13}$ Also, it is now possible to do some wedge resections and even lobectomies with video-assisted thoracoscopic surgery (VATS).

\section{Fluid management}

Perioperative fluid management for thoracic surgical cases is frequently a contentious issue between the anaesthetist and surgeon. In the 1980s several papers implicated excessive intraoperative fluid administration as a cause of postpneumonectomy pulmonary oedema. 14,15 However, recent papers suggest that even with fluid restriction, postpneumonectomy pulmonary oedema still occurs. ${ }^{16,17}$ It seems that the aetiology of this complication is multifactorial and involves lymphatic damage, right ventricular dysfunction and hyperinflation of the residual lung. ${ }^{18}$ Suggested guidelines for fluid management for pulmonary resection surgery are:

1 Total positive fluid balance at $24 \mathrm{hr}$ postoperatively should not exceed $20 \mathrm{ml} \cdot \mathrm{kg}^{-1}$. For most adults this will require administering $<2$ l crystalloid intraoperatively and $<50 \mathrm{ml} \cdot \mathrm{hr}^{-1}$ postoperatively during the first $24 \mathrm{hr}$.

From the Department of Anaesthesia, McGill University, Montreal, Quebec. 
2 No fluid replacement is required for "third space" losses during pulmonary resection surgery.

3 Urine output $>0.5 \mathrm{ml} \cdot \mathrm{kg}^{-1} \cdot \mathrm{hr}^{-1}$ is unnecessary in the early postoperative period unless there are clinical indications of developing renal insufficiency.

4 If increased tisșue perfusion is required postoperatively, it is preferable to resort to inotropes and invasive monitoring than to risk fluid overload.

\section{Intraoperative monitoring}

1 Oxygenation. The current risk of arterial oxygen desaturation during one-lung ventilation is $10-20 \% .^{19,20}$ Pulse oximetry remains far from ideal and fails too frequently in the clinical setting. ${ }^{21}$ Potential advances come from the use of monitoring sites other than the finger (buccal) and improved technology (shorter response time, greater sensitivity). Intra-arterial optodes placed via standard gauge arterial catheters can provide on-line assessment of arterial oxygen tension $\left(\mathrm{PaO}_{2}\right)$ which may permit anaesthetic intervention earlier in the course of falls in oxygenation, before actual desaturation. ${ }^{22}$ Mixed venous oximetry $\left(\mathrm{Sv}_{2}\right)$ has not proved to be clinically useful intraoperatively for most lung surgery. ${ }^{23}$

2 End-tidal $\mathrm{CO}_{2}\left(\mathrm{PETCO}_{2}\right)$. In addition to the usefulness of $\mathrm{PETCO}_{2}$ as a monitor of ventilation, it reflects matching of ventilation and perfusion. The initiation of one-lung ventilation (OLV) usually causes a transient 1-3 $\mathrm{mmHg}$ decrease in $\mathrm{PETCO}_{2}$ as the ventilation/perfusion ratio in the ventilated lung rises due to the sudden increase in physiological dead space. In the majority of patients, the $\mathrm{PETCO}_{2}$ will return close to the two-lung baseline over the next two to five minutes as hypoxic pulmonary vasoconstriction (HPV) in the non-ventilated non-dependent (ND-) lung causes a redistribution of blood flow to the ventilated dependent (D-) lung reducing the $\dot{V} / \dot{Q}$ ratio towards normal. Severe $\left(>5 \mathrm{mmHg}\right.$ ) or prolonged falls in the $\mathrm{PETCO}_{2}$ with the initiation of OLV may precede arterial oxygen desaturation.

3 Expired tidal volume and flow. Several recent-model anaesthetic ventilators (Siemens, Ohmeda) and monitors (Datex side-stream spirometer) measure expiratory tidal volume and flow. ${ }^{24,25}$ During thoracic anaesthesia, several situations may develop where the expired tidal volume falls below the inspired tidal volume: bronchopleural fistula, leak from the ventilated to the nonventilated lung during OLV, etc. These changes may not be detected by changes in the airway pressure or other routine monitors.

\section{Lung isolation}

Over $50 \%$ of all left double-lumen tubes (DLT) and
$>80 \%$ of right-DLT's that are positioned satisfactorily by auscultation will prove to be positioned inappropriately on subsequent fibreoptic bronchoscopic (FOB) surveillance. ${ }^{26}$ The FOB should be part of the routine monitors used anytime a DLT or bronchial blocker is placed. This requires that anaesthetists be completely familiar with tracheo-bronchial anatomy. ${ }^{27}$

It is important to do the FOB surveillance of the DLT position immediately before initiation of OLV. Placement of the DLT by auscultation alone is usually satisfactory, initially, to ensure that the correct side main-stem bronchus has been intubated. However, since these tubes move during patient positioning and on opening the chest, ${ }^{28}$ final "fine-tuning" of the DLT with the FOB should be done prior to the initiation of OLV. The FOBs designed specifically for anaesthesia are now commercially available.

Although absolute indications for isolation of one lung from the other (lung abscess, pulmonary haemorrhage, etc.) still occur; in the majority of cases, lung isolation is used to facilitate surgery. Successful management of one-lung isolation begins preoperatively with an estimation of the difficulty of bronchial intubation based on a review of the chest $x$-ray, bronchoscopy report and computerized tomographic (CT) scan. ${ }^{29}$ In cases with obviously distorted tracheo-bronchial anatomy the placement of a tube or blocker in the required main-stem bronchus can be done under direct FOB guidance either in the anaesthetized or awake patient. ${ }^{30}$

The best method of producing lung isolation in a given clinical situation will depend on several factors including the indication for one-lung ventilation, complicating patient factors, available equipment and skill/training of the anaesthetist. The four most commonly used methods of providing OLV are:

1 Double-lumen endobronchial tube. These tubes provide lung isolation with the greatest safety and reliability in the majority of situations. The inclusion of a carinal hook on some designs has not eliminated the requirement for FOB. Double lumen tubes are available in a variety of left- and right-sided designs. Since the left main-stem bronchus is longer than the right, the margin of safety in positioning left-sided DLTs $(15-20 \mathrm{~mm})^{31}$ is greater than for right-DLTs $(0-5 \mathrm{~mm})$. Current rightDLTs all incorporate a ventilation side-slot in the lateral wall of the bronchial lumen for ventilation and access to the right upper lobe. ${ }^{27}$ Due to individual anatomical variation, it is still impossible to achieve both adequate right upper lobe ventilation and complete one-lung isolation in about one third of cases with a right-DLT.

2 Univent tube. The Univent tube is a single-lumen endotracheal tube with an extendable bronchial blocker built into the wall of the tube. ${ }^{32}$ In practice it can be used 
in the majority of situations requiring OLV instead of a DLT. As with previous types of bronchial blockers, there is the potential for the blocker to move during surgery (particularly when placed in the right mainstem bronchus), with subsequent loss of lung isolation.

3 Endobronchial tube. A single lumen endotracheal tube: $\geq 32 \mathrm{~cm}$ length and $\leq 7.5 \mathrm{~mm}$ ID can be advanced with FOB guidance into either main-stem bronchus (preferably the left) when required for OLV. This can be useful in some emergency situations and carinal resections. However, there is no access to the nonventilated lung and it is impossible to double-check the position without impeding ventilation.

4 Bronchial Blocker. A Fogarty catheter (e.g., 8-10 Fr. venous embolectomy catheter with a $4 \mathrm{ml}$ balloon) can be passed through the glottis, external to an endotracheal tube (ETT), and inflated in the bronchus to provide OLV. With an ETT $\geq 7.0 \mathrm{~mm}$ ID in place, a Fogarty catheter and a FOB $\leq 4 \mathrm{~mm}$ diameter can be passed intra-luminally through the ETT via a bronchoscopy swivel-connector. ${ }^{33}$ The FOB can be used to direct the bronchial blocker into position, then withdrawn and the port of the swivel-connector closed around the blocker, which is left in situ. The blocker can be inflated to provide $\mathrm{OLV}$ in a variety of situations (such as multiple trauma) when changing to a DLT may not be possible or advisable.

Manufacturers are constantly modifying their doublelumen tubes and blockers based on reports of clinical performance. ${ }^{34}$ Major innovations in lung isolation equipment may be possible in the near future due to advances in materials technology. ${ }^{35}$

\section{One-lung anaesthesia}

Several factors have been shown to correlate with the decrease in $\mathrm{PaO}_{2}$ during one-lung anaesthesia: ${ }^{36}$

1 Side of operation. The right lung is a larger lung and normally receives $55 \%$ of the pulmonary perfusion. During right-thoracotomies the shunt through this lung will be larger than during left-sided surgery. On average the $\mathrm{PaO}_{2}$ is approximately $70 \mathrm{mmHg}$ lower during OLV for right thoracotomies. ${ }^{37}$

2 Preoperative decreased perfusion. If the perfusion to the operated lung is decreased preoperatively, as revealed by a $\dot{V} / Q$ scan, the decrease in $\mathrm{PaO}_{2}$ during OLV will be less. 38

3 Preoperative pulmonary function. Patients with good preoperative spirometry $\left(\mathrm{FEV}_{1} \%, \mathrm{FEV}_{\mathrm{l}} /\right.$ forced vital capacity, etc.) tend to desaturate more than others during OLV. ${ }^{39}$ The cause of this is uncertain but could be due to poorer maintenance of D-lung functional residual capacity (FRC) or less efficient HPV, in these patients. Patients having OLV for non-pulmonary in- trathoracic surgery (e.g., oesophageal, cardio-vascular etc.) tend to desaturate more than those having lung surgery, possibly because they have better spirometry. ${ }^{40}$ 4 Two-lung oxygenation. Patients with higher $\mathrm{PaO}_{2}$ values during two-lung ventilation (particularly during two-lung ventilation in the lateral position just before the onset of OLV) tend to have better $\mathrm{PaO}_{2}$ values during OLV. ${ }^{41,42}$

Thus, a patient having a right thoracotomy with a relatively low $\mathrm{PaO}_{2}\left(<400 \mathrm{mmHg}, \mathrm{FiO}_{2} 1.0\right)$ during twolung ventilation, who had good preoperative flow-rates is likely to desaturate to dangerous levels during OLV. ${ }^{36}$ In this setting, prophylactic measures to decrease the decrease in $\mathrm{PaO}_{2}$ during OLV are indicated. The most useful of such measures is the use of continuous positive airway pressure (CPAP) to the ND-lung during OLV. ${ }^{43}$

\section{Ventilation}

It is not yet possible to predict the optimal ventilatory variables for a given patient during OLV. The ideal is to maintain the ventilated D-lung as close as possible to its normal FRC since at this volume the D-lung pulmonary vascular resistance is at its minimum. Use of extrinsic positive end expiratory pressure (PEEP) to raise the FRC of the D-lung is unnecessary in most patients since they develop auto PEEP during OLV. ${ }^{44}$ The use of excessively large tidal volumes $\left(>14 \mathrm{ml} \cdot \mathrm{kg}^{-1}\right)$ leads to an increase in D-lung mean alveolar pressure which is transmitted to the pulmonary vasculature and forces perfusion back to the non-ventilated ND-lung. The use of small tidal volumes $\left(<8 \mathrm{ml} \cdot \mathrm{kg}^{-1}\right)$ in the ventilated D-lung leads to airway closure and increased D-lung shunt. ${ }^{39}$ The best ventilation plan for OLV is to maintain a normal $\mathrm{PaCO}_{2}$ using tidal volumes of $10 \mathrm{ml} \cdot \mathrm{kg}^{-1}$ and varying the respiratory rate. In healthy young patients who tend not to develop auto PEEP, the addition of 5 $\mathrm{cmH}_{2} \mathrm{O}$ extrinsic PEEP will usually be helpful. In patients with poorly compliant ND-lungs the tidal volume should be decreased to keep the peak airway pressure $<45$ $\mathrm{cmH}_{2} \mathrm{O}$.

High frequency ventilation (HFV) techniques have been used during thoracic surgery and are associated with excellent arterial oxygenation. ${ }^{45}$ However, HFV ends to dilate central airways and makes pulmonary resection surgery technically more difficult. ${ }^{46}$ However, HFV may be used for intra-thoracic non-pulmonary surgery.

\section{Anaesthetic technique}

1 The potent volatile anaesthetic agents (isoflurane, enflurane, halothane) are dose-dependent inhibitors of HPV. However, they have many benefits to offer in thoracic anaesthesia: bronchodilatation, rapid titration, rapid awakening, etc. The use of these volatile agents 
in doses $\leq 1$ MAC is not associated with an incidence of hypoxaemia during OLV that is greater than with intravenous anaesthetic techniques. ${ }^{47,48} \mathrm{The}^{\mathrm{PaO}} \mathrm{O}_{2}$ during OLV seems to depend on the agent: isoflurane $>$ enflurane $>$ halothane. ${ }^{49}$

2 Nitrous oxide $\left(\mathrm{N}_{2} \mathrm{O}\right)$ has nothing beneficial to offer during thoracic anaesthesia. Substitution of air for $\mathrm{N}_{2} \mathrm{O}$ during lung surgery has been shown to decrease the incidence of postoperative atelectasis in the D-lung. ${ }^{50}$ Nitrous oxide causes pulmonary vasoconstriction, particularly in patients with pulmonary hypertension. ${ }^{51}$ The optimal management is the use of an air/oxygen mixture titrated against the $\mathrm{SpO}_{2}$.

3 Epidural anaesthesia/analgesia (EAA). The use of combined "light general" plus epidural anaesthetic techniques for a variety of major surgical procedures has been shown to decrease morbidity and mortality. ${ }^{52}$ This has not been studied in a comparative fashion for thoracic surgery, however, non-controlled studies indicate a low incidence of postoperative morbidity with EAA..$^{53}$ The initiation of epidural analgesia prior to incision has been shown to decrease postoperative pain and opioid requirements. ${ }^{54}$

\section{Hypoxaemia during one-lung ventilation}

As in any case of intraoperative hypoxaemia, problems with oxygen supply (inappropriate $\mathrm{FiO}_{2}$ ) or ventilation (migration of a double-lumen tube to obstruct a lobar bronchus) must be ruled out. Having eliminated other potential causes, hypoxaemia during OLV is usually due to the increased shunt in the ND-lung. Several therapies are available to treat hypoxaemia during OLV:

1 Use of a high inspired oxygen concentration $\left(\mathrm{FiO}_{2}\right)$. The incidence of hypoxaemia is lower when a high $\mathrm{FrO}_{2}$ (e.g., 1.0) is used during OLV. ${ }^{55,56}$ However, it is not always advisable to use a high $\mathrm{FrO}_{2}$. A growing list of drugs which includes bleomycin, ${ }^{57}$ amiodarone ${ }^{58,59}$ and mitromycin- $\mathrm{C}^{60}$ has been associated with postoperative respiratory failure when a high $\mathrm{FIO}_{2}$ was used intraoperatively for thoracic surgery.

2 Continuous positive airway pressure (CPAP) to the ND-lung (i.e., the "collapsed" lung). This is by far the next most reliable treatment of hypoxaemia during OLV and it is rare that additional therapy is needed..$^{43}$ Disposable CPAP circuits are commercially available and simple CPAP circuits can be quickly constructed from a variety of equipment available in most anaesthetic departments. Several points must be appreciated about the use of ND-lung CPAP during OLV: (i) CPAP to the ND-lung is of little/no benefit if it is applied to a collapsed lung. The ND-lung must be reinflated prior to connection to the CPAP circuit. ${ }^{61}$ When applied in this fashion, low levels of CPAP (2-3
$\mathrm{cmH}_{2} \mathrm{O}$ ) can be used. ${ }^{62}$ (ii) CPAP will be of little/ no clinical benefit when a major bronchus of the NDlung is open to atmosphere (e.g., bronchial sleeve resection, broncho-pleural fistula) or obstructed (endobronchial tumour). (iii) The optimal gas mixture to use for ND-lung CPAP has not been studied. The majority of investigations have used $\mathrm{FiO}_{2} 1.0$ (practically this is the simplest). However, air $/ \mathrm{O}_{2}$ CPAP mixtures can also provide good arterial oxygenation during OLV and avoid some of the problems associated with prolonged exposure to high $\mathrm{FIO}_{2}$ levels.

3 PEEP to the dependent lung. D-lung extrinsic PEEP causes a decrease in $\mathrm{PaO}_{2}$ during OLV in the majority of patients. ${ }^{39}$ However, a minority of patients, often those who have the lowest $\mathrm{PaO}_{2}$ levels during OLV, benefit from D-lung PEEP. It is best to apply D-lung PEEP only after CPAP has been applied to the NDlung. Since the majority of anaesthetic ventilators cannot measure auto-PEEP, it is useful to use one (e.g., Siemens $900-C$ ) or an airway pressure monitor (e.g., Datex Capnomac) that permits end-expiratory interruption and measurement of the total PEEP delivered to the patient. Applied (extrinsic) PEEP and auto (intrinsic) PEEP combine in an unpredictable fashion to produce the total PEEP, which the patient experiences. ${ }^{44}$ If hypoxaemia persists, the optimal combination CPAP/PEEP should be sought using alternating $5 \mathrm{cmH}_{2} \mathrm{O}$ increments of each.

4 Manipulation of the tidal volume to the ventilated $\mathrm{D}$ lung. Patients who have a low $\mathrm{PaO}_{2}$ with a small VT to the D-lung $\left(7 \mathrm{ml} \cdot \mathrm{kg}^{-1}\right)$ may show improved $\mathrm{PaO}_{2}$ with a larger VT $\left(14 \mathrm{ml} \cdot \mathrm{kg}^{-1}\right)$ and vice versa. ${ }^{39}$

5 Re-inflation of the ND-lung. This impedes surgery but can be done intermittently (e.g., every five minutes) as a "fall-back" technique when the above techniques have not succeeded. ${ }^{63}$ This can allow an operation to proceed that would otherwise have to be aborted.

6 Obstruction of the ipsilateral pulmonary artery. This can only be done in a clinically reliable fashion by surgical clamping. It can be useful in pneumonectomies and lung transplantation.

7 Pharmacological manipulation. Although theoretically possible, no pharmacological intervention such as discontinuing the volatile anaesthetic or altering the cardiac output has yet proved to be consistently useful as a treatment for hypoxaemia during OLV.

\section{Video-assisted thoracoscopic surgery (VATS)}

Advances in videoscopic technology have permitted the recent exponential increase in the applications of VATS. Undoubtedly, VATS will become the procedure of choice for many lesser intrathoracic procedures: bleb-bullae resection, biopsies, sympathectomies etc. A wide range of 
other procedures: lobectomy, oesophageal surgery, PDA ligation etc., are also possible with VATS. ${ }^{64}$ Initial reports of anaesthesia for VATS used essentially the same management as for standard thoracotomies. ${ }^{20}$ However, experience with the technique has shown that there are several specific differences:

1 Pain and postoperative pulmonary function. Postoperative pain is considerably less following VATS than after thoracotomy. Also, the early postoperative loss of pulmonary function is less. The loss of FEV 1 post-VATS is about half that expected after thoracotomy. ${ }^{65}$ This has led thoracic surgeons to lower the minimal acceptable cutoff for preoperative pulmonary function. Patients with $\mathrm{FEV}_{1}<30 \%$ predicted (e.g., $<0.8 \mathrm{l}$ ) and/ or $\mathrm{CO}_{2}$ retention may now be offered segment/wedge resection for carcinoma.

2 Carbon dioxide insufflation. Due to elastic recoil, the operated lung will collapse on exposure to atmospheric pressure to facilitate surgery and insufflation of $\mathrm{CO}_{2}$ is usually unnecessary. Insufflation of $\mathrm{CO}_{2}$ into the hemi-thorax during VATS has led to reports of intraoperative haemodynamic instability. ${ }^{66}$ However, a study of $\mathrm{CO}_{2}$ insufflation found no serious haemodynamic changes with up to $14 \mathrm{mmHg}$ intrapleural gas pressure. ${ }^{67}$ The aetiology of the reports of haemodynamic collapse remains unclear.

3 Spontaneous ventilation. At the beginning of this century anaesthetists recognized that controlled ventilation was necessary to prevent hypoxaemia and hypoventilation whenever the hemi-thorax was open. During VATS, although the pressure in the operative hemithorax is approximately atmospheric, the chest is not really "open." Careful titration of volatile anaesthetics and opioids permits spontaneous ventilation during thoracoscopy after the surgeon has allowed air to enter the hemi-thorax to collapse the operative lung. ${ }^{68,69}$ Spontaneous ventilation for VATS: (i) Avoids the use of a double-lumen tube or bronchial blocker, either of which are time consuming, expensive and increase the risk of tracheo-bronchial trauma. (ii) Avoids the use of controlled ventilation, which is desirable in patients with fistulae or bilateral bullae. (iii) Gives superior oxygenation during one-lung anaesthesia due to better ventilation/perfusion matching.

\section{Postoperative analgesia}

1 Does it make a difference? Few studies have addressed the impact of analgesia on post-thoracotomy outcome or pulmonary function. However, there does seem to be a pattern that patients with better analgesia have better. spirometry and fewer respiratory complications. ${ }^{70,71}$

2 Is there a superior method? Reasonable clinical com- parisons indicate that neuraxial opioid analgesia (spinal/epidural) with/without additional local anaesthetic is superior to other methods of opioid administration or the multitude of other modalities (cryoanalgesia, intrapleural analgesia, TENS etc.) for post-thoracotomy analgesia. ${ }^{72}$ Preemptive analgesia is also a factor in epidural pain relief. ${ }^{54}$ The method of analgesia should be extended to the 24-72 $\mathrm{hr}$ postoperative period when recovery of pulmonary function is particularly delayed following thoracic incisions. ${ }^{73}$

3 Are thoracic and lumbar epidurals equivalent? This seems to depend on the lipid solubility of the opioid. For low lipid solubility agents such as morphine, lumbar epidurals work well post-thoracotomy. For high lipid solubility agents, the site of the epidural injection needs to be as close to the incision as possible. ${ }^{74}$ The use of low lipid solubility drugs is associated with an increased incidence of side effects due to increased rostral spread in the CSF. ${ }^{75}$

4 Is there a good alternative to epidural analgesia? Due to coagulation disorders, anatomical problems, etc., many patients are not candidates for epidural analgesia. The best alternative seems to be the use of a continuous paravertebral local anaesthetic nerve block with a catheter placed either by the surgeon when the chest is open $^{76,77}$ or percutaneously. This is combined with intravenous opioid supplementation via a patientcontrolled analgesia (PCA) pump.

\section{Summary}

The major recent advances in thoracic anaesthesia include:

1 Improved prediction of patients at risk of postoperative respiratory failure.

2 Improved intraoperative monitoring of oxygenation and ventilation.

3 Improved double-lumen tubes and bronchial blockers to provide lung isolation.

4 The routine use of fibreoptic bronchoscopy to aid in the positioning double-lumen tubes or blockers.

5 The ability to predict which patients are most at risk for becoming hypoxaemic during one-lung anaesthesia.

6 The prophylactic use of appropriately applied CPAP.

7 Spontaneous ventilation during thoracoscopy.

8 Postoperative neuraxial analgesia.

\section{References}

1 Ginsberg RJ, Hill LD, Eagan RT, et al. Modern thirty-day operative mortality for surgical resections in lung cancer. $J$ Thorac Cardiovasc Surg 1983; 86: 654-8.

2 Smith TP, Kinasewitz GT, Tucker WY, Spillers WP, George $R B$. Exercise capacity as a predictor of post- 
thoracotomy morbidity. Ann Rev Respir Dis 1984; 129: 730-4.

3 Drigs $P$. Preoperative assessment of lung cancer. Chest 1989; 96: 42S-44S.

4 Kearney DJ, Lee TH, Reilly JJ, DeCamp MM, Sugarbaker DJ. Assessment of operative risk in patients undergoing lung resection. Chest 1994; 105: 753-9.

5 Nakahara K, Mouden Y, Ohno K, Miyoski S, Maeda H, Kawashima $Y$. A method for predicting postoperative lung function and its relation to postoperative complications in patients with lung cancer. Ann Thorac Surg 1985; 39: 260-5.

6 Parot S, Saunier C, Gauthier H, Milic-Emili J, Sadoul P. Breathing pattern and hypercapnia in patients with obstructive pulmonary disease. Am Rev Respir Dis 1980; 121 : 985-91.

7 Pierce RJ, Copland JM, Sharpe K, Barter CE. Preoperative risk evaluation for lung cancer resection: predicted postoperative product as a predictor of surgical mortality. Am J Respir Crit Care Med 1994; 150: 947-55.

8 Ferguson $M K$, Little $L$, Rizzo $L$, et al. Diffusing capacity predicts morbidity and mortality after pulmonary resection J Thorac Cardiovasc Surg 1988; 96: 894-900.

9 Wernley JA, DeMeester TR, Kirchner PT, Myerowitz PD, Oxford $D E$, Golomb $H M$. Clinical value of quantitative ventilation-perfusion lung scans in the surgical management of bronchogenic carcinoma. J Thorac Candiovasc Surg 1980; 80: 535-43.

10 Morice RC, Peters EJ, Ryan MB, Putman JB, Ali $M K$, Roth $J A$. Exercise testing in the evaluation of patients at high risk for complications from lung resection. Chest 1992; 101: 356-61.

11 Bolton JWR, Weiman DS, Haynes $J L$, Hornung CA, Olsen GN, Almond CH. Stair climbing as an indicator of pulmonary function. Chest 1987; 92: 783-8.

12 Shirakusa $T$, Tsutsui $M$, Iriki $N$, et al. Results of resection for bronchogenic carcinoma in patients over the age of 80 . Thorax 1989; 44: 189-91.

13 Urschel HC, Razzuk MA. Median sternotomy as a standard approach for pulmonary resection. Ann Thorac Surg 1986; 41: 130-4.

14 Zeldin RA, Normandin D, Landtwing BS, Peters RM. Postpneumonectomy pulmonary edema. J Thorac Cardiovasc Surg 1984; 87: 359-65.

15 Verheijen-Breemharr L, Bogaard JM, Van Den Berg B, Vilvering $C$. Post pneumonectomy pulmonary edema. Thorax 1988; 43: 323-6.

16 Waller DA, Gebitekin C, Saunders NR, Waler DR. Noncardiogenic pulmonary edema complicating lung resection. Ann Thorac Surg 1993; 55: 140-3.

17 Turnage WS, Lunn JL. Postpneumonectomy pulmonary edema. A retrospective analysis of associated variables. Chest 1993; 103: 1646-50.
18 Slinger $P$. Perioperative fluid management for thoracic surgery: the puzzle of postpneumonectomy pulmonary edema. J Candiothorac Vasc Anesth (in press).

19 Hurford $W E$, Alfille $P H$. A quality improvement study of the placement and complications of double-lumen endobronchial tubes. J Cardiothorac Vasc Anesth 1993; 7: 517-20.

20 Barker SJ, Clarke C, Trivedi N, Hyatt J, Fynes M, Roessler $P$. Anesthesia for thoracoscopic laser ablation of bullous emphysema. Anesthesiology 1993; 78: 44-50.

21 Haessler MD, Brandl F, Zeller $M$, Breigel J, Peter $K$. Continuous intra-arterial oximetry, pulse oximetry and cooximetry during cardiac surgery. J Cardiothorac Vasc Anesth 1992; 6: 668-73.

22 Greenblott GB, Tremper KK, Barker SJ, Gershultz S, Gehrich $J L$. Continuous blood gas monitoring with an intraarterial optode during one-lung anesthesia. J Cardiothorac Vasc Anesth 1991; 4: 365-7.

23 Thys DM, Cohen E, Eisenkraft JB. Mixed venous oxygen saturation during thoracic anesthesia. Anesthesiology 1988; 69: 1005-9.

24 Simon BA, Hurford WE, Alfille PH, Haspel K, Behringer $E C$. An aid in the diagnosis of malpositioned doublelumen tubes. Anesthesiology 1992; 76: 862-3.

25 Bardoczy GI, Levarlet $M$, Engelman $E$, Defrancquen $P$. Continuous spirometry for detection of double-lumen endobronchial tube displacement. $\mathrm{Br} \mathrm{J}$ Anaesth 1993; 70: 499-502.

26 Zbinden S. Fibreoptic bronchoscopy and double-lumen tubes (Letter). Can J Anaesth 1993; 40: 681.

27 Slinger $P$. Fiberoptic bronchoscopic positioning of doublelumen tubes. J Cardiothoracic Anesthesia 1989; 3: 486-96.

28 Alliaume B, Coddens J, Deloof $T$. Reliability of auscultation in positioning double-lumen endobronchial tubes. Can J Anaesth 1992; 39: 387-90.

29 Saito $S$, Dohi $S$, Tajima $K$. Failure of double-lumen endobronchial tube placement: congenital tracheal stenosis in an adult. Anesthesiology 1987; 66: 83-5.

30 Patane PS, Sell BA, Mahla M. Awake fiberoptic endobronchial intubation. Journal of Cardiothoracic Anesthesia 1990; 4: 229-31.

31 Benumof $J L$, Partridge BL, Salvatierra $C$, Keating $J$. Margin of safety in positioning modern double-lumen endotracheal tubes. Anesthesiology 1987; 67: 729-38.

32 Gayes JM. Pro: one-lung ventilation is best accomplished with the Univent endobronchial tube. J Cardiothorac Vasc Anesth 1993; 7: 103-7.

33 Zilbertstein M, Katz RI, Levy A, Reyes R, Popper PJ. An improved method for introducing an endobronchial blocker. Journal of Cardiothoracic Anesthesia 1990; 4: 481-3.

34 Slinger $P$, Chripko D. A clinical comparison of bronchial cuff pressures in three different designs of left double-lumen tubes. Anesth Analg 1993; 79: 305-8. 
35 Kolobow T, Tsuno K, Rossi N, Aprigliano M. Design and development of ultrathin-walled nonkinking endotracheal tubes of new "non-pressure" laryngeal seal design. Anesthesiology 1994; 81: 1061-7.

36 Slinger P, Suissa S, Triolet W. Predicting arterial oxygenation during one-lung anaesthesia. Can J Anaesth 1992; 39: $1030-5$.

37 Lewis JW, Serwin JP, Gabriel FS, Bastaufar M, Jacobsen $G$. The utility of a double-lumen tube for one-lung ventilation in a variety of non cardiac thoracic surgical procedures. J Cardiothorac Vasc Anesth 1992; 6: 705-10.

38 Hurford WE, Kolkar $A C$, Strauss $H W$. The use of ventilation/perfusion lung scans to predict oxygenation during one-lung anesthesia. Anesthesiology 1987; 64: 841-4.

39 Katz $J A$, Lavern $R G$, Fairley HB, Thomas $A N$. Pulmonary oxygen exchange during endobronchial anesthesia: effect of tidal volume and PEEP. Anesthesiology 1982; 56: 164-70.

40 Kerr JH, Crampton Smith A, Prys-Roberts $C$, Meloche $R$, Fö̈x $P$. Observations during endobronchial anesthesia II: oxygenation. Br J Anaesth 1974; 46: 84-92.

41 Read RC, Friday $C D$, Eason $C N$. Prospective study of the Robertshaw endobronchial catheter in thoracic surgery. Ann Thorac Surg 1977; 24: 156-61.

42 Flacke JW, Thompson DS, Read RC. Influence of tidal volume and pulmonary artery occlusion on arterial oxygenation during endobronchial anesthesia. South Med J 1976; 69: 619-26.

43 Capan LM, Turndorf H, Patel C, et al. Optimization of arterial oxygenation during one-lung anesthesia. Anesth Analg 1980; 68: 763-6.

44 Slinger PD, Hickey DR, Lenis SG, Gottfried S. Intrinsic PEEP during one-lung ventilation. Anesth Analg 1989; 68 : S269.

45 Godet G, Bertrand $M$, Rouby JJ, et al. High frequency jet ventilation versus continuous positive airway pressure for differential lung ventilation in patients undergoing resection of thoracoabdominal aortic aneurysm. Acta Anaesthesiol Scand 1994; 38: 562-8.

46 Glenski $J A$, Crawford $M$, Rehder $K$. High-frequency small-volume ventilation during thoracic surgery. Anesthesiology 1986; 64: 211-4.

47 Benumof $J L$, Augustine SD, Gibbons $J A$ Halothane and isoflurane only slightly impair arterial oxygenation during one-lung ventilation in patients undergoing thoracotomy. Anesthesiology 1987; 67: 910-5.

48 Reid $C W$, Slinger $P$, Lenis $S$. A comparison of the effects of isoflurane vs propofol-alfentanil anaesthesia on oxygenation during one-lung ventilation. Can J Anaesth 1993; 40: $A 68$.

49 Slinger $P$, Scott WAC. Arterial oxygenation during onelung ventilation: a comparison of enflurane and isoflurane. Anesthesiology 1993; 79: A1231.
50 Browne DRG, Rochford J, O'Connell U, Jones:JG. The incidence of postoperative atelectasis in the dependent lung following thoracotomy: the value of added nitrogen. $\mathrm{Br} \mathrm{J}$ Anaesth 1970; 42: 340-6.

51 Schulte-Sasse U, Hess W, Tarnow J. Pulmonary vascular responses to nitrous oxide in patients with normal and high pulmonary vascular resistance. Anesthesiology 1982; 57: 9-13.

52 Yeager MP, Glass DD, Neff RK, Brinek-Johnsen T. Epidural anesthesia and analgesia in high-risk surgical patients. Anesthseiology 1987; 66: 729-36.

53 Temeck BK, Schafer PW, Park WY, Harmon JW Epidural anesthesia in patients undergoing thoracic surgery. Arch Surg 1989; 124: 415-8.

54 Katz J, Kavanagh BP, Sandler AN, et al. Preemptive analgesia. Clinical evidence of neuroplasticity contributing to postoperative pain. Anesthesiology 1992; 77 : 439-46.

55 Thompson DF, Campbell $D$. Changes in arterial oxygen tension during one-lung anaesthesia. Br J Anaesth 1973; 45: 611-6.

56 Tarhan $S$, Lundborg $R O$. Effects of increased expiratory pressure on blood gas tensions and pulmonary shunting during thoracotomy with the use of the Carlens catheter. Can Anaesth Soc J 1970; 17: 4-11.

57 Ingrassia TS III, Ryu JH, Trastek VF, Rosenow EC III. Oxygen-exacerbaterd bleomycin pulmonary toxicity. Mayo Clin Proc 1991; 66: 173-8.

58 Morrow B, Shorten GD, Sylvester W. Postoperative amiodarone pulmonary toxicity. Anaesth Intensive Care 1993; 21: 361-2.

59 Van Mieghem $W$, Coolen L, Malysse I, Lacquet LM, Deneffe GJD, Demedts MGP. Amiodarone and the development of ARDS after lung surgery. Chest 1994; 105: 1642-5.

60 Thompson CC, Bailey MK, Conroy JM, Bromley HR. Postoperative pulmonary toxicity associated with mitomycin-C therapy. South Med J 1992; 85: 1257-9.

61 Slinger $P$, Triolet $W$, Wilson J. Improving arterial oxygenation during one-lung ventilation. Anesthesiology 1988; 68: 291-5.

62 Hogue $C W$. Effectiveness of low levels of nonventilated lung continuous positive airway pressure in improving arterial oxygenation during one-lung ventilation. Anesth Analg 1994; 79: 364-7.

63 Malmkvist $G$. Maintenance of oxygenation during onelung ventilation. Effect of intermittent reinflation of the collapsed lung with oxygen. Anesth Analg 1989; 68: 763-6.

64 The first international symposium in thoracoscopic surgery. Ann Thorac Surg 1993; 56: 605-804.

65 Waller DA, Forty J, Morrit GN. Video-assisted thoracoscopic surgery versus thoracotomy for spontaneous pneumothorax. Ann Thorac Surg 1994; 58: 372-7. 
66 Peden CJ, Prys-Roberts C. Capnothorax: implications for the anaesthetist. Anaesthesia 1993; 48: 664-6.

67 Wolfer RS, Krasna MJ, Hasnain JU, McLaughlin JS. Hemodynamic effects of carbon dioxide insufflation during thoracoscopy. Ann Thorac Surg 1994; 58: 404-8.

68 Ryckman FC, Rodgers BM. Thoracoscopy for intrathoracic neoplasia in children. J Ped Surg 1982; 17: 521-4.

69 Robinson JS, Slinger P, Mulder D, Shennib H. Video assisted thorascopic surgery using a single lumen tube in spontaneously ventilating anesthetised patients: an alternative technique. J Cardiothorac Vasc Anesth (in press).

70 Guinard J-P, Mavrocordatos $P$, Chiolero R, Carptener RL. A randomized comparison of intravenous versus lumbar and thoracic epidural fentanyl for analgesia after thoracotomy. Anesthesiology 1992; 77: 1108-15.

71 Slinger $P$, Shennib $H$, Wilson S. Post-thoracotomy pulmonary function: a comparison of epidural versus intravenous meperidine infusions. J Cardiothorac Vasc Anesth (in press).

72 Kavanagh BP, Katz J, Sandler AN. Pain control after thoracic surgery: a review of current techniques. 1994; 81 : 737-59.

73 Ali J, Weisel RD, Layug AB, Kripke BJ, Hechtman HB. Consequences of postoperative alterations in respiratory mechanics. Am J Surg 1974; 128: 376-82.

74 Benzon HT. Post-thoracotomy epidural analgesia: lumbar or thoracic placement? J Cardiothorac Vasc Anesth 1993; 7: 515-6.

75 Asentila $R$, Rosenberg $P H$, Scheinin B. Comparison of different methods of postoperative analgesia after thoracotomy. Acta Anaesthesiol Scand 1986; 30: 421-5.

76 Berrisford $R G$, Sabanathan $S$. Direct access to the paravertebral space at thoracotomy (Letter). Ann Thorac Surg 1990; 49: 854 .

77 Berrisford RG, Sabanathan S, Mearns AJ, Clarke BJ, Hamdi A. Plasma concentrations of bupivacaine and its enantiomers during continuous extrapleural intercostal nerve block. Br J Anaesth 1993; 70: 201-4. 


\section{Nouveautés en anesthé- sie pour la chirurgie thoracique incluant la thoracoscopie}

Cette conférence traitera des plus récents progrès pertinents à la gestion anesthésique de patients soumis à une chirurgie thoracique. Les domaines spécifiques qui ont fait l'objet d'innovations dignes de mention sont les suivants: l'évaluation préopératoire, le monitorage peropératoire, la thoracoscopie et l'analgésie postopératoire.

\section{L'évaluation préopératoire}

Les taux de morbidité et de mortalité de la résection pulmonaire sont les plus élevés de toute les interventions chirurgicales non urgentes. Les taux de mortalité opératoire à 30 jours se situent environ à $4 \%^{1}$ et des complications cardiorespiratoires graves surviennent dans $30-50 \%{ }^{2}$ des cas. Les candidats à la chirurgie rencontrent ordinairement les critères minimaux d'opérabilité. ${ }^{3} \mathrm{Ce}$ pendant, parmi les sujets admissibles à la résection pulmonaire, ceux dont les risques de mortalité et de morbidité périopératoires sont élevés devraient être identifiés selon les critères suivants:

1 La fonction pulmonaire préopératoire: le volume expiré maximal seconde (VEMS) est l'indicateur individuel le plus utile de la morbidité précoce. ${ }^{4}$ Un VEMS postopératoire inférieur à $40 \%$ de la normale prédite est associé à une augmentation de la morbidité et de la mortalité. La majorité des patients dont le VEMS est inférieur à $30 \%$ auront besoin de support ventilatoire à une moment ou l'autre de la période postopératoire. ${ }^{5}$

Une proportion importante des patients admis pour une chirurgie thoracique souffre de maladie pulmonaire obstructive chronique (MPOC). Parmi les porteurs d'une MPOC modérée ou grave (VEMS $<65 \%$ de la valeur prédite), il est impossible de prédire sur la base de l'amamnèse, de l'examen physique et de la spirométrie, lesquels présenteront une rétention de $\mathrm{CO}_{2}{ }^{6}$ Ils faut considérer tous ces patients comme des candidats à la ventilation mécanique après la thoracotomie. Ainsi, pour aider le sevrage postopératoire de tous les patients qui souffrent de MPOC, il faut exiger une analyse préopératoire des gaz artériels.

La capacité de diffusion du monoxyde de carbone (DLCO) est un prédicteur indépendant des complications respiratoires post-thoracotomie. ${ }^{7}$ Une DLCO préopéra- toire de $80 \%$ supérieure à la capacité de diffusion prédite est associée à une incidence de complications respiratoires postopératoires inférieure à 10\%; une DLCO de $60 \%$ inférieure à la capacité prédite est associée à un risque supérieur à $30 \%{ }^{8}$ Pour une pneumonectomie anticipée, l'importance du risque peut être atténuée sur la base de la scintigraphie ventilation/perfusion $(\dot{\mathrm{V}} / \dot{\mathrm{Q}}){ }^{{ }^{9}}$

Les épreuves de tolérance à l'exercice peuvent être considérées comme les prédicteurs les plus spécifiques de complications cardiopulmonaires post-thoracotomie. Une consommation d'oxygène maximale $\left(\dot{\mathrm{VO}}_{2} \max \right)$ supérieure à $20 \mathrm{ml} \cdot \mathrm{kg}^{-1} \cdot \min ^{-1}$ est associée à une incidence faible de complications; une $\mathrm{VO}_{2}$ max inférieure à $15 \mathrm{ml} \cdot \mathrm{kg}^{-1} \cdot \min ^{-1}$ présente un risque très élevé. ${ }^{10} \mathrm{~L}$ 'ascension d'un escalier constitue une épreuve équivalente mais plus difficilement reproductible. "I

2 L'âge: des études récentes suggèrent que l'âge n'est plus un facteur indépendant de risque de mortalité; 12 il est toutefois reconnu que le taux de morbidité augmente avec l'âge avancé.

3 L'incision: plusieurs résections pulmonaires peuvent être réalisées par sternotomie médiane. Cette incision est associée à un taux inférieur de morbidité et à une meilleure fonction pulmonaire postopératoire. ${ }^{13}$ En outre, il est maintenant aussi possible d'effectuer des résections cunéiformes et même des lobectomies par chirurgie thoracoscopique assistées par vidéo (CTAV).

\section{La gestion de l'apport hydrique}

En chirurgie thoracique, la gestion des apports hydriques fait souvent l'objet de débats entre le chirurgien et l'anesthésiste. Au cours des années 1980, plusieurs articles de revue tenaient l'administration excessive de liquides peropératoires en partie responsable de l'oedème pulmonaire après la pneumonectomie. ${ }^{14,15}$ Cependant, des articles récednts suggèrent que même avec la restriction serrée des liquides, l'oedème pulmonaire postpneumonectomie peut encore survenir. ${ }^{16,17}$ Il semble que, dans l'étiologie de cette complication, plusieurs facteurs interviennent dont l'endommagement des lymphatiques, le dysfonctionnement ventriculaire droit et l'hyperinflation du poumon résiduel. ${ }^{18}$ Pour la résection pulmonaire, il 
est suggéré de gérer l'apport hydrique de la façon suivante:

$1 \mathrm{La}$ balance liquidienne positive totale à la $24 \mathrm{e} \mathrm{h}$ qui suit lintervention ne devrait pas dépasser $20 \mathrm{ml} \cdot \mathrm{kg}^{-1}$. Pour la plupart des adultes, ceci nécessite une administration inférieure à $2 \mathrm{~L}$ de cristalloìde pendant l'intervention et moins de $50 \mathrm{ml} \cdot \mathrm{h}^{-1}$ pour les premières $24 \mathrm{~h}$ qui suivent lintervention.

2 Il n'est pas nécessaire de remplacer le liquide d'un " troisième espace " pendant une chirurgie de résection.

3 Un débit urinaire plus grand que $0,5 \mathrm{ml} \cdot \mathrm{kg}^{-1} \cdot \mathrm{h}^{-1}$ n'est pas nécessaire au cours de la période postopératoire immédiate à moins qu'on ait des indices cliniques nous permettant d'anticiper une évolution vers linsuffisance rénale.

4 Sil est nécessaire d'augmenter la perfusion tissulaire apres l'intervention, il est préférable d'avoir recours à des inotropes associé à un monitorage effractif plutôt que de risquer une surcharge liquidienne.

\section{Monitorage peropératoire}

1 L'oxygénation. Le risque actuel d'une désaturation en oxygène pendant la ventilation unipulmonaire est de 10 à $20 \%{ }^{19,20}$ L'oxymétrie de pouls est loin de lidéal et, dans le contexte clinique, tombe trop souvent en panne. ${ }^{21}$ Il est possible d'améliorer son rendement en utilisant un site de monitorage autre que le doigt (par ex., la bouche) et en tirant profit d'une technologie plus avancée (temps de réponse plus court, sensibilité plus grande). Une optode introduite a travers une canule artérielle standard peut fournir une évaluation " en ligne " de la tension du sang artériel en oxygène $\left(\mathrm{PaO}_{2}\right)$; ceci permet à l'anesthésiste d'intervenir instantanément et, avant la désaturation, lors d'une baisse de l'oxygénation. ${ }^{22}$ L'oxymétrie du sang veineux mêle $\left(\mathrm{S} \mathrm{O}_{2}\right)$ n'a pas fait la preuve de son utilité pendant la chirurgie dans la grande majorité des cas de chirurgie pulmonaire. ${ }^{23}$

$2 \mathrm{La} \mathrm{CO}_{2}$ téléexpiratoire $\left(\mathrm{PETCO}_{2}\right)$. En plus de monitorer la ventilation, la capnographie reflète l'harmonisation de la ventilation avec la perfusion. Linitiation de la ventilation unipulmonaire (VUP) provoque une baisse transitoire de la $\mathrm{PeTCO}_{2}$ de l'ordre de 1 à $3 \mathrm{mmHg}$ au moment où le rapport ventilation-perfusion du poumon ventilé s'elève par augmentation subite de l'espace mort physiologique. Dans la majorité des cas, la $\mathrm{PETCO}_{2}$ revient très près de la valeur initiale au cours des 2 à 5 min suivantes, lorsque la vasoconstriction pulmonaire hypoxique (VPH) du poumon non ventilé supérieur (poumon-S) redistribue le débit sanguin au poumon inférieur ventilé (poumon-I), se qui ramène le rapport $\dot{V} / \dot{Q}$ vers une valeur normale. Au moment de la mise en marche de la VUP, des chutes plus importantes $>5 \mathrm{mmHg}$ ) ou prolongées de la $\mathrm{PETCO}_{2}$ peuvent précéder une désaturation artérielle en oxygène.

3 Les débits et volumes expirés. Plusieurs modèles plus récents de ventilateurs d'anesthésie (Siemens, Ohmeda) et de moniteurs (spiromètre Datex) permettent de mesurer les volume et débits expirés. ${ }^{24,25}$ Pendant l'anesthésie thoracique, plusieurs situations, au cours de la VUP, peuvent provoquer des baisses du volume courant expiré sous le niveau du volume inspiré: par ex., une fistule bronchopleurale, une fuite de gaz du poumon ventilé vers le poumon non ventilé, etc. Ces changements peuvent être décelés par les altérations de pression des voies aériennes ou par les autres moniteurs conventionnels.

\section{L'exclusion pulmonaire}

Plus de 50\% des tubes à double lumière (TDL) gauches et plus de $80 \%$ des tubes droits dont la position a été jugée correcte sous contrôle auscultatoire sont par la suite jugés en mauvaise position par la bronchoscopie fibroptique (BFO). ${ }^{26}$ On devrait toujours avoir recours à la BFO chaque fois qu'on installe un TDL ou un bloqueur bronchique. Ceci exige de la part de l'anesthésiste une connaissance complète de l'anatomie trachéobronchique. ${ }^{27}$

Il est important de vérifier la position du TDL immédiatement avant linitiation de la VUP. La vérification par auscultation seule est habituellement satisfaisante au début car elle nous permet de nous assurer que la bronche souche désirée est intubée. Cependant, comme les tubes peuvent se déplacer pendant linstallation du patient et à l'ouverture du thorax, ${ }^{28}$ une dernière mise au point sous BFO devrait être effectuée avant le début de la VUP. A cet effet, des BFO spécialement conçus pour l'anesthésie sont maintenant disponibles.

Bien qu'll existe des indications absolues pour l'exclusion d'un poumon (abcès pulmonaires, hémorragies pulmonaires, etc.), dans la majorité des cas, l'exclusion d'un poumon est réalisée dans le but de faciliter la chirurgie. Pour réussir, la manoeuvre d'exclusion doit débuter à la période préopératoire en évaluant à l'aide de la radiographie pulmonaire si lintubation endobronchique sera facile ou non. Il faut aussi tenir compte de la consultation du bronchoscopiste et du rapport de la tomodensitométrie. ${ }^{29}$ Lorsque l'anatomie trachéobronchique est de toute évidence altérée, le placement d'un tube ou d'un bloqueur dans le bronche souche devrait se faire sous vision directe en utilisant le BFO comme guide, que $œ$ soit chez un patient éveillé ou anesthésié. ${ }^{30}$

Pour une situation donnée, la meilleure méthode d'exclusion pulmonaire dépendra de plusieurs facteurs dont: 
les indications de la ventilation unipulmonaire, les facteurs de complications propres au patient et de la disponibilité du matériel auxquels il faut ajouter lhabileté et l'expérience de l'anesthésiste. Les quatre méthodes les plus fréquemment utilisées pour procurer de la VUP sont: 1 Le tube endobronchique à double lumière. Dans la majorité des situations, ce sont ces tubes qui permettent l'exclusion pulmonaire avec la plus grande sécurité et la plus grande fiabilité. Certains modèles comportent un ergot pour la carène, ce qui n'élimine pas la nécessité de la BFO. Une grande variété de modèles de TDL gauches et droits sont disponibles. Comme la bronche souche gauche est plus longue que la droite, la marge de sécurité pour un TDL gauche $(15-20 \mathrm{~mm})^{31}$ est plus élevée que pour un TDL droit $(0-5 \mathrm{~mm})$. Les TDL droits sont dotés d'une fenêtre latérale pour la ventilation et l'accès au lobe supérieur droit. ${ }^{27} \mathrm{~A}$ cause des variations anatomiques individuelles, il demeure impossible d'assurer à la fois une ventilation adéquate du lobe supérieur droit et l'exclusion complète d'un poumon avec un TDL droit dans environ un tiers des cas.

2 Le tube Univent. Le tube Univent est un tube endobronchique à une seule lumière avec un bloqueur bronchique coulissant incorporé à la paroi du tube..$^{32}$ En pratique, il peut être utilisé à la place d'un TDL dans la majorité des situations qui nécessitent la VUP. Comme avec tous les bloqueurs plus anciens, il est toujours possible que le bloqueur se déplace pendant la chirurgie (spécialement sil est placé dans la bronche souche droite) avec la perte de l'exclusion du poumon.

3 Le tube endobronchique. Un simple tube endobronchique dont la longueur est plus grande ou égale à $32 \mathrm{~cm}$ et le diamètre plus petit ou égal à $7,5 \mathrm{~mm}$ (diamètre interne) peut être descendu sous vision par BFO dans liune ou l'autre des bronches (preférablement la gauche) lorsque la VUP est nécessaire. Cette technique peut être utile dans certaines situations d'urgence et pour les résections de la carène. Cependant, on perd l'accès au poumon non ventilé et il devient impossible de vérifier la position du tube sans entraver la ventilation.

4 Le bloqueur bronchique. Un cathéter de Fogarty (un cathéter d'embolectomie 8-10 Fr avec un ballonnet de $4 \mathrm{ml}$ ) peut être introduit à travers la glotte, à l'extérieur d'un tube endotrachéal (TET) et gonflé dans la bronche pour réaliser la VUP. De la même façon, avec un TET $(\geq 7,0 \mathrm{~mm})$ en position, un cathéter de Fogarty de diamètre plus petit ou égal à $4 \mathrm{~mm}$ peut être dirigé dans la lumière du TET à travers le raccord à pivot servant à lintroduction du BFO. ${ }^{33}$ Le BFO sert à diriger le bloqueur vers sa position, puis est retiré et on scelle l'ouverture du raccord à pivot autour du bloqueur laissé en bonne position. Le bloqueur est gonflé lorsque la situation l'exige (par ex., un polytraumatisme), lorsqu'il est impossible d'utiliser un TLD, et qu'il devient nécessaire de ventiler un seul poumon.

Toujours à l'écoute de la performance, les manufacturiers modifient constamment leurs TDL et leurs bloqueurs. ${ }^{34} \mathrm{~A}$ l'avenir, grâce aux progrès de la technologie des matériaux, nous pouvons nous attendre à des innovations majeures dans le domaine de l'exclusion pulmonaire. ${ }^{35}$

\section{L'anesthésie unipulmonaire}

On connait plusieurs des facteurs susceptibles de faire baisser la $\mathrm{PaO}_{2}$ pendant l'anesthésie unipulmonaire: ${ }^{36}$

1 Le côté opéré. Le poumon droit est le plus volumineux et reçoit normalement 55\% de la perfusion. Pendant les thoracotomies droites, le shunt intrapulmonaire sera plus important que pendant une chirurgie qui intéresse le poumon gauche. En moyenne, au cours d'une thoracotomie droite, la $\mathrm{PaO}_{2}$ est d'environ plus basse d'environ $70 \%$ pendant la VUP. ${ }^{37}$

2 L'état préopératoire de la perfusion. Si la perfusion du poumon opéré est déjà diminuée avant linntervention, comme pourrait le montrer la scintigraphie $\dot{\mathrm{V}} / \dot{\mathrm{Q}}$, la chute de la $\mathrm{PaO}_{2}$ sera moins importante. ${ }^{38}$

$3 \mathrm{La}$ fonction pulmonaire préopératoire. Sous VUP, les patients dont la spirométrie préopératoire est bonne (VEMS, VEMS/capacité vitale forcée, etc.) ont tendance à se désaturer plus profondément que les autres. ${ }^{39}$ La cause en est incertaine mais ceci pourrait être dû, chez ces patients, à l'incapacité du poumonI de maintenir sa capacité résiduelle fonctionnelle (CRF) et à une VPH moins efficace. Les patients soumis à la VUP pour une chirurgie intrathoracique non pulmonaire (par ex., oesophagienne, cardiovasculaire, etc.) ont tendance à se désaturer plus profondément que ceux qui subissent une chirurgie pulmonaire, vraisemblablement parce que leur spirométrie est généralement normale. ${ }^{40}$

$4 \mathrm{La}$ ventilation bipulmonaire. Les patients possédant les valeurs de $\mathrm{PaO}_{2}$ les plus élevées pendant la ventilation bipulmonaire (particulièrement pendant la ventilation bipulmonaire en position latérale précédant la VUP) ont ordinairement les meilleurs $\mathrm{PaO}_{2}$ pendant la VUP. ${ }^{41,42}$

Ainsi un patient qui subit une thoracotomie droite avec une $\mathrm{PaO}_{2}$ relativement basse $\left(<400 \mathrm{mmHg}, \mathrm{FlO}_{2} 1,0\right)$ pendant la ventilation bipulmonaire et qui avait à la période préopératoire des bons débits est susceptible de désaturer à des niveaux dangereusement bas pendant la VUP. ${ }^{36}$ Sous ces conditions, il est indiqué de prendre avant la VUP des mesures préventives pour éviter cette chute de la $\mathrm{PaO}_{2}$. La plus utile de ces mesures consiste 
à exercer une pression positive continue (CPAP) sur le poumon-S pendant la VUP. ${ }^{43}$

\section{La ventilation}

Pendant la VUP, on ne peut prédire présentement les paramètres de ventilation optimaux pour un patient donné. Lidéal serait de maintenir une CRF normale, étant donné qu'avec ce volume la résistance vasculaire pulmonaire du poumon-I est à son plus bas niveau. L'utilisation d'une pression positive extrinsèque en fin d'expiration (PEEP) pour augmenter la CRF du poumonI n'est pas nécessaire chez la plupart des patients parce qu ils développent une auto-PEEP pendant la VUP. ${ }^{44}$ Lutilisation de volumes courants trop élevés $>14$ $\mathrm{ml} \cdot \mathrm{kg}^{-1}$ ) conduit à une augmentation de la pression alveolaire moyenne du poumon-I qui se transmet à la vasculature pulmonaire et reflue la perfusion dans le poumon-S non ventilé. L'utilisation de petits volumes courants $\left(<8 \mathrm{ml} \cdot \mathrm{kg}^{-1}\right)$ au poumon-I ventilé conduit à la fermeture des voies aériennes et à l'augmentation du shunt dans le poumon-I. ${ }^{39} \mathrm{La}$ meilleure stratégie ventilatoire pour la VUP consiste à maintenir une $\mathrm{PaCO}_{2}$ normale avec des volumes courants de $10 \mathrm{ml} \cdot \mathrm{kg}^{-1}$ et de faire varier la fréquence respiratoire. Chez les sujets jeunes et en bon état qui ne développent pas d'autoPEEP, l'addition d'un PEEP extrinsèque de $5 \mathrm{~cm} \mathrm{H}_{2} \mathrm{O}$ sera ordinairement utile. Chez les patients dont le poumon-S est peu compliant, le volume courant devrait être diminué pour garder une pression maximale sur les voies aériennes inférieure à $45 \mathrm{~cm} \mathrm{H}_{2} \mathrm{O}$.

La ventilation à haute fréquence (VHF) a été utilisée en chirurgie thoracique et procure une excellente oxygénation artérielle. ${ }^{45}$ Cependant, la VHF tend à dilater les voies aériennes centrales et rend ainsi la résection pulmonaire techniquement plus difficile. ${ }^{46} \mathrm{La}$ VHF peut s'avérer utile pour la chirurgie intrathoracique non pulmonaire.

\section{La technique anesthésique}

1 Les agents anesthésiques volatils puissants (isoflurane, enflurane, halothane) inhibent la VPH proportionnellement à leur concentration. Cependant, ils offrent plusieurs avantages pour l'anesthésie thoracique: la bronchodilatation, la facilité d'administration, le réveil précoce, etc. L'usage de ces agents volatils à des concentrations inférieures ou égales à MAC 1 pendant la VUP ne s'accompagne pas d'une incidence plus élevée d'hypoxémie que celle qu'on rencontre avec les agents intraveineux. ${ }^{47,48} \mathrm{La} \mathrm{PaO}_{2}$ pendant la VUP semble aussi dépendre en partie de l'agent: isoflurane $>$ enflurane $>$ halothane. ${ }^{49}$

2 En anesthésie thoracique le protoxyde d'azote $\left(\mathrm{N}_{2} \mathrm{O}\right)$ n’a aucun bénéfice à offrir. Il a déjà été démontré que le remplacement du $\mathrm{N}_{2} \mathrm{O}$ par l'air pendant la chirurgie du poumon diminuait lincidence de l'atélectasie postopératoire dans le poumon-I. ${ }^{50}$ Le $\mathrm{N}_{2} \mathrm{O}$ produit de la vasoconstriction pulmonaire surtout chez le porteur d'hypertension pulmonaire. ${ }^{51}$ La gestion optimale consiste à utiliser un mélange air/oxygène réglé selon la $\mathrm{SPO}_{2}$.

3 L'anesthésie/analgésie épidurale (AAE). Il a été démontré pour plusieurs types d'intervention chirurgicales que l'utilisation d'une combination d'anesthésie générale "légère » et d'anesthésie épidurale diminuait la morbidité et la mortalité. ${ }^{52}$ Bien qu'aucune comparaison du même type n'ait été établie avec la chirurgie thoracique, des études non contrôlées rapportent une morbidité postopératoire inférieur avec l'AAE. ${ }^{53} \mathrm{La}$ mise en marche de l'analgésie épidurale avant l'incision diminuerait la douleur postopératoire et la demande de morphiniques. ${ }^{54}$

\section{Lhypoxémie pendant la ventilation unipulmonaire}

Lorsque l'hypoxémie se manifeste pendant l'intervention, il faut, comme à la période postopératoire, rechercher la carence de l'apport en oxygène ( $\mathrm{FIO}_{2}$ trop basse) ou l'insuffisance de la ventilation (par ex., la migration d'un TDL obstruant une bronche lobaire). Une fois les autres causes possible éliminées, l'hypoxémie pendant la VUP est ordinairement produite par l'augmentation du shunt intrapulmonaire du poumon-S. On peut traiter cette hypoxémie de différentes façons:

1 En augmentant la concentration d'oxygène $\left(\mathrm{FIO}_{2}\right)$. Lincidence de l'hypoxémie est plus faible quand on utilise une $\mathrm{FrO}_{2}$ élevée (par ex., 1,0) pendant la VUP. ${ }^{55,56}$ Cependant, il n'est pas toujours sage d'utiliser une $\mathrm{FIO}_{2}$ élevée. Une liste croissante de drogues dont la bléomycine, ${ }^{57}$ l'amiodarone ${ }^{58,59}$ et la nitromycine-C $\mathrm{C}^{60}$ ont été associées à l'insuffisance respiratoire postopératoire lorsque le patient est exposé pendant la chirurgie à une $\mathrm{FIO}_{2}$ élevée.

2 L'application d'une pression positive continue (CPAP) sur le poumon-S (c.-à-d. le poumon collabé). Ceci représente la méthode la plus fiable de traiter l'hypoxémie durant la VUP et il est rare qu'elle échoue ${ }^{43}$ Des circuits de CPAP jetables sont disponibles et on peut, de plus, construire des circuits simples avec le matériel disponible dans la plupart des départements d'anesthésie. Au regard de l'application de CPAP sur le poumon$S$ pendant la VUP, il faut tenir compte des points suivants: i) Un CPAP appliqué au poumon-S collabé ne présente que peu ou pas d'avantages. Il faur réinsuffler le poumon-S avant de le relier au circuit de CPAP. ${ }^{61}$ De cette façon, des niveaux peu élevés de CPAP (2-3 $\mathrm{cm} \mathrm{H}_{2} \mathrm{O}$ ) peuvent être utilisés. ${ }^{62}$ ii) Le CPAP ne présentera aucun avantage clinique lorsqu'une bronche de 
gros calibre est en communication avec l'atmosphere (par ex., résection d'une section bronchique, correction d'une fistule pleurale) ou obstruée (tumeur endobronchique). iii) Le mélange de gaz optimal pour la CPAP du poumon-S n'a pas fait l'objet d'études. La grande partie des recherches s'est concentrée sur la $\mathrm{FIO}_{2}=$ 1,0 (les plus faciles à réaliser). Les mélanges pour CPAP air $/ \mathrm{O}_{2}$ peuvent procurer une aussi bonne oxygénation et nous mettre à l'abri de certains problèmes associés aux expositions prolongées à des niveaux élevés de $\mathrm{FIO}_{2}$.

3 La PEEP sur le poumon inférieur. Pendant la VUP, une PEEP extrinsèque sur le poumon inférieur produit une baisse de $\mathrm{PaO}_{2}$ chez la plupart des patients. ${ }^{39} \mathrm{Ce}-$ pendant, quelques patients, souvent ceux dont la $\mathrm{PaO}_{2}$ est la plus basse pendant la VUP, bénéficient dune PEEP sur le poumon-I. Il est préférable d'appliquer la PEEP sur le poumon-I seulement après quune CPAP a été appliquée au poumon-S. Comme la majorité des ventilateurs ne sont pas capables de mesurer l'auto-PEEP, il est utile de fair appel à un ventilateur comme le Siemens $900-\mathrm{C}$ ou à un moniteur de pression des voies aériennes (par ex., le Datex Capnomac) qui permettent en fin d'expiration linterruption et la mesure de la PEEP totale fournie au patient. La PEEP appliquée (extrinsèque) et l'auto-PEEP (intrinsèque) se combinent de façon imprévisible pour produire le PEEP total que le paqtient reçoit. ${ }^{44} \mathrm{Si}$ l'hypoxémie persiste, la combinaison optimale CPAP/PEEP devrait être recherchée en alternant des plateaux de $5 \mathrm{~cm} \mathrm{H}_{2} \mathrm{O}$ de chacun des types pressions positives.

$4 \mathrm{La}$ manipulation des volumes courants du poumon$\mathrm{I}$ ventile. Une $\mathrm{PaO}_{2}$ basse avec un VT faible (7 $\mathrm{ml} \cdot \mathrm{kg}^{-1}$ ) peut être rétablie avec un VT plus important $\left(14 \mathrm{ml} \cdot \mathrm{kg}^{-1}\right)$ et vice-versa. ${ }^{39}$

5 La réinsufflation du poumon-S. Celle-ci entrave la chirurgie mais on peut la réaliser de façon intermittente (par ex., toutes les $5 \mathrm{~min}$ ) comme technique de sauvetage lorsque les techniques déjà mentionnées ont échoué. ${ }^{63}$ Ceci peut permettre de terminer une intervention qui autrement aurait dû être avortée.

6 L'obstruction de l'artère pulmonaire homolatérale. Elle ne peut être réalisée de façon fiable que par clampage chirurgical. Cette méthode est utile pour les pneumonectomies et les transplantations pulmonaires.

7 La manipulation pharmacologique. Bien que possible théoriquement, aucune intervention pharmacologique telle que l'arrêt de l'anesthésique volatil ou l'altération du débit cardiaque n'a fait la preuve de son efficacité pour traiter l'hypoxémie pendant la VUP.

La chinurgie thoracoscopique assistée par vidéo (CTAV) Grâce aux progrès de la technologie vidéoscopique, les applications de la CTAV connaissent une montée fulgurante. Sans aucun doute, la CTAV deviendra la technique de choix pour une foule d'interventions d'importance mineure: résection de bulles d'emphysème, biopsies, sympathectomies, etc. Beaucoup d'autres interventions sont aussi réalisables par CTAV: lobectomie, chirurgie oesophagienne, ligature de canal artériel, etc. ${ }^{64}$ Les premières recommandations sur l'anesthésie pour la CTAV préconisaient la même gestion que pour la thoracotomie standard. ${ }^{20}$ Cependant, l'expérience nous a montré quil fallait tenir compte de différence spécifiques importantes:

$1 \mathrm{La}$ douleur et la fonction pulmonaire postopératoires. La douleur postopératoire est beaucoup moins intense après la CTAV qu'après la thoracotomie. La perte immédiate de fonction pulmonaire est aussi moins importante. La diminution du VEMS ne represente que la moitié de celle qui survient après une thoracotomie. ${ }^{65}$ Ceci a conduit à la révision à la baisse par le chirurgien de la norme de fonction préopératoire minimale exigée auparavant. Les cancéreux dont la VEMS est de moins de $30 \%$ de la VEMS prédite (par ex., $<0,8 \mathrm{~L}$ ) avec ou sans rétention de $\mathrm{CO}_{2}$ sont acceptés pour une résection en coin ou segmentaire.

2 Linsufflation de $\mathrm{CO}_{2}$. A cause de son élasticité, le poumon du côté de l'intervention se collabe sous l'effet de la pression atmosphérique facilitant ainsi la chirurgie; en général l'insufflation de $\mathrm{CO}_{2}$ n'est pas nécessaire. Linsufflation de $\mathrm{CO}_{2}$ dans l'hémithorax pendant la CTAV produirait selon certaines études de linstabilité hémodynamique ${ }^{66} \mathrm{Cependant,} \mathrm{une} \mathrm{étude} \mathrm{réalisée}$ pendant l'insufflation de $\mathrm{CO}_{2}$ ne n'a pas révélé de changements hémodynamiques importants lorsque la pression intrapleurale était gardée sous $14 \mathrm{mmHg} .{ }^{67} \mathrm{~L}$ 'étiologie du collapsus hémodynamique derneure inconnue.

3 La ventilation spontanée. Dès le début du siècle, les anesthésistes ont reconnu la nécessité du contrôle de la ventilation pour la prévention de l'hypoxémie et de l'hypoventilation à thorax ouvert. Pendant la CTAV, bien que la pression mesurée à l'intérieur de l'hémithorax soit à peu près atmosphérique, le thorax n'est pas réellement " ouvert ". Le titrage soigné des anesthésiques volatils et des morphiniques permet la ventilation spontanée pendant la thoracoscopie après l'admission d'air provoquée par le chirurgien dans l'hémithorax pour collaber le poumon du côté l'intervention. ${ }^{68,69}$ La ventilation spontanée pour une CTAV: i) évite le besoin d'un TDL et d'un bloqueur bronchique; les deux consomment du temps, coûtent cher et augmentent le risque de traumatisme trachéobronchique, ii) évite la ventilation contrôlée excepté pour la résection de bulles d'emphysèmes bilatérales et la fermeture de fistules. iii) fournit une oxygénation plus 
efficace pendant la VUP par une meilleure harmonisation $\dot{V} / \dot{Q}$.

\section{Quant à l'analgésie postopératoire}

1 Fait-elle une différence? Peu d'étude se sont attardées à mesurer limpact de l'analgésie sur les résultats de la thoracotomie et sur la fonction pulmonaire après celle-ci. Cependant, les patients bien analgésiés profitent d'une amélioration de la spirométrie et présentent moins de complications respiratoires. ${ }^{70,71}$

2 Devons-nous favoriser une méthode en particulier? Des comparaisons valides montrent que l'analgésie régionale médullaire aux morphiniques (rachidienne et épidurale) avec ou sans ajout d'anesthésiques locaux est, pour l'analgésie postthoracotomie, supérieur aux autres méthodes d'administration de morphiniques ou à une multitude d'autres modalités (cryoanalgésie, analgésie intrapleurale, TENS, etc.). ${ }^{72}$ L'analgésie préventive représente aussi un facteur à considérer pour le soulagement épidural de la douleur. ${ }^{54} \mathrm{Il}$ faudrait aussi prolonger l'analgésie pour une période de $24-72 \mathrm{~h}$ après l'intervention alors que la récupération de la fonction pulmonaire est retardée par la douleur de lincision thoracique. ${ }^{73}$

3 L'épidurale lombaire est-elle équivalente à l'épidurale thoracique? Ceci semble dépendre de la liposolubilité du morphinique. Pour les agents peu liposolubles comme la morphine, l'épidurale lombaire est efficace. Pour les agents très liposolubles, le site de l'injection doit être aussi près que possible du site de l'incision. ${ }^{74}$ Les agents peu liposolubles sont associés à plus d'effets secondaires par la progression rostrale de la morphine dans le LCR. ${ }^{75}$

4 Existe-t-il une bonne alternative à l'analgésie épidurale? A cause de problèmes de coagulation, d'anatomie, etc., plusieurs patients ne peuvent profiter d'une épidurale. La meilleure alternative semble lutilisation de blocs paravertébraux continus aux anesthésiques locaux avec un cathéter transcutané ou mis en place par le chirurgien lorsque le thorax est ouvert. ${ }^{76,77}$ Cette technique est complétée par l'analgésie intraveineuse contrôlée par le patient (PCA).

\section{Résumé}

Les progrès récents de l'anesthésie thoraciques s'enoncent comme suit:

1 Amélioration de la prédiction du risque dinsuffisance respiratoire après la chirurgie.

2 Amélioration peropératoire du monitorage de l'oxygénation et de la ventilation.

3 Amélioration des tubes à deux lumières et des bloqueurs bronchiques.

4 Consécration de la bronchofibroscopie pour la mise en place des tubes à deux lumières et des bloqueurs bronchiques.

5 Amélioration des prédicteurs pour les patients les plus à risque d'hypoxémie pendant l'anesthésie unipulmonaire.

6 Usage préventif de la CPAP.

7 Analgésie médullaire postopératoire.

\section{Références}

(Voir page R81) 